\title{
Pengaruh Pemberian Dadih Terhadap Keseimbangan Mikroflora Usus dan Tinggi Vili Ileum
}

Yusri Dianne Jurnalis

Bagian Ilmu Kesehatan Anak Fakultas Kedokteran Universitas Andalas/RSUP Dr. M. Djamil, Padang

Latar belakang. Saat ini dikembangkan paradigma baru bahwa probiotik dapat menjadi suplemen terapi diare. Di Sumatera Barat sendiri dikenal probiotik tradisional, yaitu dadih yang merupakan produk susu kerbau fermentasi.

Tujuan. Menilai pengaruh pemberian dadih terhadap keseimbangan mikroflora dan tinggi vili ileum mencit diare yang diinduksi dengan Enteropathogenic Escherichia coli (EPEC).

Metode. Penelitian ini menggunakan metode eksperimental dengan rancangan randomized post test only control group. Sampel adalah 30 ekor mencit diinduksi dengan bakteri EPEC. Penelitian dilakukan pada Juni 2016 sampai Mei 2017.

Hasil. Rerata total koloni bakteri asam laktat (BAL) meningkat pada kelompok perlakuan dibandingkan dengan kontrol positif dan kontrol negatif $(\mathrm{p}<0,05)$. Rerata total koloni bakteri patogen dan E.coli menurun pada kelompok perlakuan dibandingkan kelompok kontrol positif dan kontrol negatif ( $\mathrm{p}=0,001)$. Tinggi vili ileum tidak menunjukkan perbedaan yang bermakna. Namun, pada kelompok perlakuan gambaran histopatologis menunjukkan destruksi epitel hanya 30\% dan terjadinya reaksi imunologis terhadap infeksi EPEC dibuktikan dengan ditemukannya proliferasi limfoid dilapisan submukosa vili ileum.

Kesimpulan. Terdapat pengaruh pemberian dadih terhadap keseimbangan mikroflora, tetapi tidak berpengaruh pada tinggi vili ileum. Sari Pediatri 2019;21(4):207-12

Kata kunci: dadih, keseimbangan mikroflora, tinggi vili ileum, mencit

\section{The Effect of Dadih Administration on Intestinal Microflora Balance and Ileum Villus Height}

Yusri Dianne Jurnalis

Background. A new paradigm has been developed that probiotics can be used as supplement for diarrhea therapy. West Sumatera has traditional probiotic known as dadih made from fermented buffalo milk.

Objective. To assess the effect of dadih administration on intestinal microflora balance and ileum villous height in diarrhea mice induced by EPEC.

Methods. This was an experimental study using Randomized Post Test Only Control Group design. 30 mices were induced with EPEC. The study was conducted in June 2016 to May 2017.

Result. The mean total LAB colonies increased in treatment group compared to positive and negative controls $(\mathrm{p}<0.05)$. The mean total colony of pathogenic bacteria and E.coli decreased in treatment group compared to positive and negative control ( $\mathrm{p}=0.001$ ). There were no significant differences in ileum villus height between groups $(\mathrm{p}=0.707)$. However, in treatment group, histopathological features showed epithelial destruction of only $30 \%$ and immunological reactions to EPEC infection showed by lymphoid proliferation in ileum submucosal layer.

Conclusion. There is an effect of dadih administration on microflora balance but not villous ileum height. Sari Pediatri 2019;21(4):20712

Keywords: dadih, microflora balance, ileum villus height, mice

Alamat korespondensi: Yusri Dianne Jurnalis. Departemen Ilmu Kesehatan Anak Fakultas Kedokteran Universitas Andalas/ RSUP dr.M.Djamil Jl. Perintis Kemerdekaan. Padang, Sumatera Barat. Email: dianneyusri5@gmail.com. 
Yusri Dianne Jurnalis: Pengaruh pemberian dadih terhadap keseimbangan mikroflora usus dan tinggi vili ileum

$\mathrm{D}$ iare didefinisikan sebagai keluarnya feses cair lebih dari 3 kali sehari. Diare merupakan tanda dari adanya infeksi di saluran pencernaan yang disebabkan oleh bakteri, virus, maupun parasit. Infeksi dapat menyebar melalui makanan atau minuman yang terkontaminasi, atau dari satu orang ke orang lain karena higiene yang buruk. Terapi baku pada diare akut sesuai pedoman WHO adalah pemberian cairan rehidrasi (oral atau parenteral) dan pemberian zinc selama 10-14 hari serta pemberian dietetik. ${ }^{1}$

Pada diare terjadi perubahan histologi usus, terutama diare yang disebabkan oleh infeksi. Diare menyebabkan histologi usus berubah, vili menjadi pendek, sel epitel kuboid berkurang, sehingga mengganggu fungsi dari mukosa usus dan menyebabkan diare menjadi semakin berat. ${ }^{2}$ Infeksi oleh bakteri patogen menyebabkan perubahan mikroekologi usus dan ketahanan kolonisasi mukosa usus sehingga terjadi gangguan keseimbangan mikroflora. Keseimbangan mikroflora adalah suatu keadaan yang akan tercapai apabila mikroba yang menguntungkan dapat menekan mikroba yang merugikan dengan cara mendesak keluar mikroba patogen tersebut, yang tampak pada stabilnya jumlah bakteri dalam usus, meningkatnya jumlah bakteri anaerob atau bakteri asam laktat (BAL), rendahnya jumlah bakteri patogen (bakteri patogen) dan dapat ditekannya jumlah bakteri E.coli pada taraf yang tidak membahayakan bagi kesehatan saluran cerna. ${ }^{3-5}$

Saat ini dikembangkan suatu paradigma baru memanipulasi keberadaan mikroorganisme probiotik dalam usus dan memelihara mikroekosistem sehingga dapat mencegah terjadinya kolonisasi bakteri patogen penyebab diare, serta memicu respon imun mukosa yang akan memproduksi IgA yang sangat berperan dalam imunitas humoral lokal mukosa usus (local humoral mucosal immunity) dan mucosal cell mediated immunity (CMI). ${ }^{6}$ Probiotik mengandung bakteri asam laktat (BAL) yang berpotensi meningkatkan imunitas, meningkatkan proses absorpsi oleh vili usus, pergerakan usus, mencegah intoleransi, antimutagenik ${ }^{2}$ dan menurunkan kolesterol. ${ }^{7}$

Di Sumatera Barat sudah dikenal probiotik tradisional yang sering disebut dengan dadih. Dadih merupakan produk susu kerbau fermentasi yang merupakan bahan pangan tradisional. ${ }^{8}$ Bakteri asam laktat dalam dadih dapat menghambat kolonisasi bakteri patogen dalam usus ${ }^{9}$ dan menurunkan $\mathrm{pH}$ usus menjadi 3-4,5 sehingga petumbuhan bakteri patogen akan terhambat. ${ }^{10,11}$

Berdasarkan uraian di atas, penelitian ini dianggap perlu dilakukan karena sampai saat ini penelitian mengenai peranan bakteri asam laktat dalam terapi diare hanya dilakukan dengan menggunakan isolat probiotik komersial atau isolat dadih, sedangkan penelitian yang menggunakan dadih secara utuh untuk terapi diare akut belum pernah dilakukan. Oleh karena itu, penelitian ini dilakukan untuk membuktikan pengaruh pemberian dadih sebagai probiotik terhadap keseimbangan mikroflora dan tinggi vili ileum melalui analisis eksperimental pada mencit diare yang diinduksi dengan EPEC.

\section{Metode}

Penelitian ini menggunakan metode eksperimental dengan rancangan randomized control trial. Penelitian dilakukan antara Juni 2016 hingga Mei 2017 di Laboratorium Farmasi, Laboratorium Teknologi Hasil Ternak, Laboratorium Biomedik dan Laboratorium Patologi Anatomi Fakultas Kedokteran Universitas Andalas. Populasi penelitian ini adalah mencit putih jantan berumur 6-8 minggu dengan berat 20-30 gram yang dinduksi dengan EPEC. Jumlah sampel adalah 30 ekor mencit yang dibagi dalam 3 kelompok penelitian. Mencit yang sakit atau mati selama periode penelitian dieksklusikan dari penelitian. Mencit dibagi dalam 3 kelompok secara acak. Kelompok kontrol negatif tidak diberikan perlakuan, kelompok kontrol positif diinduksi dengan EPEC, tetapi tidak diberikan dadih, dan kelompok perlakuan diinduksi dengan EPEC kemudian diberikan dadih. Kelompok kontrol positif dan perlakuan diinduksi dengan EPEC yang mengandung $108 \mathrm{CFU} / \mathrm{ml}$ sebanyak $1 \mathrm{ml} /$ hari. Dadih yang digunakan berasal dari Bukittinggi, Sumatera Barat, dan diberikan per oral dengan sondage 112 $\mathrm{mg} / 20 \mathrm{grBB} /$ mencit.

Keseimbangan mikroflora usus diperiksa pada sampel usus halus mecit, bagian ileum, sebanyak 1 gr pada hari terakhir perlakuan, diikuti dengan penghitungan koloni bakteri yang terdiri dari BAL, bakteri aerob, dan E. coli (bakteri oportunistik dan anaerob fakultatif). Penghitungan total koloni dilakukan menggunakan Quebec colony counter. Tinggi vili ileum diukur dengan mengambil ileum usus seanyak $5 \mathrm{~cm}$, kemudian sampel histologis diukur 
menggunakan mikroskop optik dengan pembesaran 200x.

Data yang diambil tersebut dimasukkan ke dalam program perangkat lunak SPSS ${ }^{\odot} 22$. Data dianalisis menggunakan ANOVA satu arah apabila sebaran data normal dan varian data sama, atau menggunakan uji Kruskal-Wallis apabila sebaran data tidak normal atau varian data tidak sama. Bila pada uji ANOVA satu arah atau Kruskall-Wallis diperoleh hasil yang signifikan, dilakukan analisis post-hoc. Analisis post-hoc untuk ANOVA satu arah adalah Bonferroni, sedangkan untuk uji Kruskall-Wallis adah Mann Whitney. Tingkat kemaknaan dinyatakan bila $\mathrm{p}<0,05$.

\section{Hasil}

Penelitian berlangsung selama 14 hari pada 30 ekor mencit yang memenuhi kriteria inklusi.

Tabel 1 memperlihatkan rerata total koloni BAL meningkat pada mencit kelompok perlakuan yang diberi dadih (100,70 cfu/gram), sedangkan rerata total koloni BAL menurun pada kelompok kontrol positif yang tidak diberi dadih $(34,90 \mathrm{cfu} / \mathrm{gram})$ $(\mathrm{p}<0,001)$, serta terdapat perbedaan yang signifikan pada perbandingan antara 2 kelompok penelitian.

Tabel 1 juga memperlihatkan perbedaan rerata total koloni bakteri patogen yang bermakna antara ketiga kelompok $(\mathrm{p}=0,001)$. Rerata total koloni bakteri patogen meningkat pada kelompok kontrol positif yang tidak diberi dadih $(8,10 \mathrm{cfu} / \mathrm{gram})$, sedangkan rerata total koloni bakteri patogen pada kelompok perlakuan yang diberi dadih (1,60 cfu/gram) jumlahnya menurun. Penelitian menunjukkan perbedaan dari total koloni bakteri patogen pada mencit kelompok kontrol positif dan negatif $(\mathrm{p}=0,002)$ dan mencit pada kelompok kontrol positif dan perlakuan $(\mathrm{p}=0,001)$, tetapi tidak ditemukan perbedaan antara mencit kelompok perlakuan dan kontrol negatif $(p=0,434)$.

Tabel 2 memperlihatkan rerata total koloni bakteri E.coli meningkat pada mencit kelompok kontrol positif yang tidak diberi dadih (3,30 cfu/gram), sedangkan rerata total koloni bakteriE.colimenurun pada kelompok perlakuan yang diberi dadih $(1,00$ cfu/gram) ( $\mathrm{p}=0,001)$ (Tabel 3). Terdapat perbedaan yang signifikan secara statistik $(\mathrm{p}=0,001)$ pada mencit kelompok kontrol negatif, kontrol positif, dan perlakuan masing-masingnya .

Tabel 1. Rerata total koloni BAL dan bakteri patogen pada mencit kelompok kontrol negatif, positif, dan perlakuan

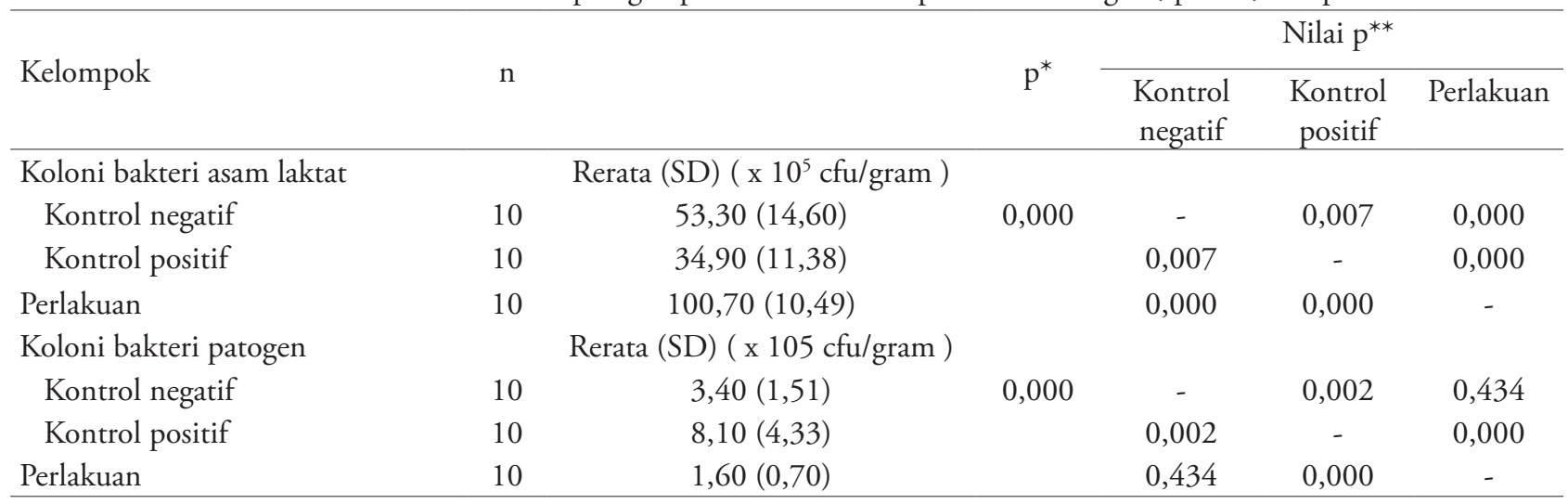

Tabel 2. Rerata total koloni bakteri E. coli pada mencit kelompok kontrol negatif, positif, dan perlakuan

\begin{tabular}{lccclll}
\hline Kelompok & $\mathrm{n}$ & $\begin{array}{l}\text { Rerata (SD) } \\
\text { cfu/gram })\end{array}$ & $\mathrm{p}^{*} 10^{*}$ & \multicolumn{3}{c}{ Nilai $^{* *}$} \\
\cline { 5 - 7 } & 10 & $2,10(0,57)$ & 0,000 & $\begin{array}{l}\text { Kontrol } \\
\text { negatif }\end{array}$ & $\begin{array}{l}\text { Kontrol } \\
\text { positif }\end{array}$ & Perlakuan \\
\hline Kontrol negatif & 10 & $3,30(0,82)$ & & 0,000 & 0,000 & 0,001 \\
Kontrol positif & 10 & $1,00(0,00)$ & & 0,001 & 0,000 & - \\
Perlakuan & & & &
\end{tabular}


Tabel 3. Rerata tinggi vili ileum pada mencit kelompok kontrol negatif, positif, dan perlakuan*

\begin{tabular}{lccc}
\hline Kelompok & $\mathrm{n}$ & Rerata (SD) & $\mathrm{p}$ \\
\hline Kontrol negatif & 10 & $0,24(0,06)$ & 0,707 \\
Kontrol positif & 10 & $0,26(0,06)$ & \\
Perlakuan & 10 & $0,25(0,05)$ & \\
\hline
\end{tabular}

${ }^{*}$ Analisis menggunakan ANOVA satu arah

Tabel 3 menunjukkan tidak terdapat perbedaan yang signifikan tinggi vili ileum pada mencit kelompok negatif, positif, dan perlakuan $(p>0,707)$. Secara mikroskopis, pada kelompok kontrol negatif tampak jaringan ileum dengan mukosa yang utuh, sedangkan pada vili ileum kelompok kontrol positif tampak jaringan ileum dengan mukosa yang sebagian besar (75\%) mengalami detruksiepitel, lamina propria mengandung sebukanringan dan kelompokan limfosit dan leukosit PMN. Pada kelompok perlakuan, tampak jaringan ileum dengan mukosa yang sebagian $(30 \%)$ mengalami detruksi epitel, lamina propria mengandung sebukan ringan dan kelompokan limfosit dan leukosit PMN. Tampak pula proliferasi folikel limfoid di lapisan submukosa yang merupakan bukti terjadinya reaksi imunologis terhadap infeksi Enteropathogenic Eschericia coli (Gambar 1). Pada penelitian ini tidak terdapat pengaruh pemberian dadih terhadap tinggi vili ileum pada mencit yang mengalami diare akut, tetapi pada mencit yang tidak mendapat dadih terlihat kerusakan epitel mukosa vili ileum.

\section{Pembahasan}

Rerata total koloni BAL yang didapatkan pada penelitian ini lebih tinggi pada kelompok perlakuan dibandingkan dengan kontrol positif dan negatif dengan perbedaan yang bermakna secara statistik. Hal ini menunjukkan bahwa BAL dalam dadih mampu melekat pada mukosa usus halus yang akan menghambat bakteri lain. Enterosit yang telah jenuh dengan bakteri probiotik tidak dapat lagi mengadakan perlekatan dengan bakteri lain sehingga dengan adanya bakteri probiotik di dalam mukosa usus dapat mencegah kolonisasi bakteri pathogen. ${ }^{12-14}$

$\mathrm{Hal}$ ini didukung oleh penelitian Diarlin $\mathrm{dkk}^{3} \mathrm{di}$ Malang yang mendapatkan bahwa terdapat peningkatan total koloni BAL setelah pemberian probiotik Lactobacillus fermentum dan Lactobacillus salivarius pada ayam pedaging. ${ }^{3}$ Penelitian lain oleh Arief $\mathrm{dkk}^{15}$ di Bogor juga menunjukkan bahwa total BAL pada tikus sehat dan tikus sakit yang diberikan probiotik

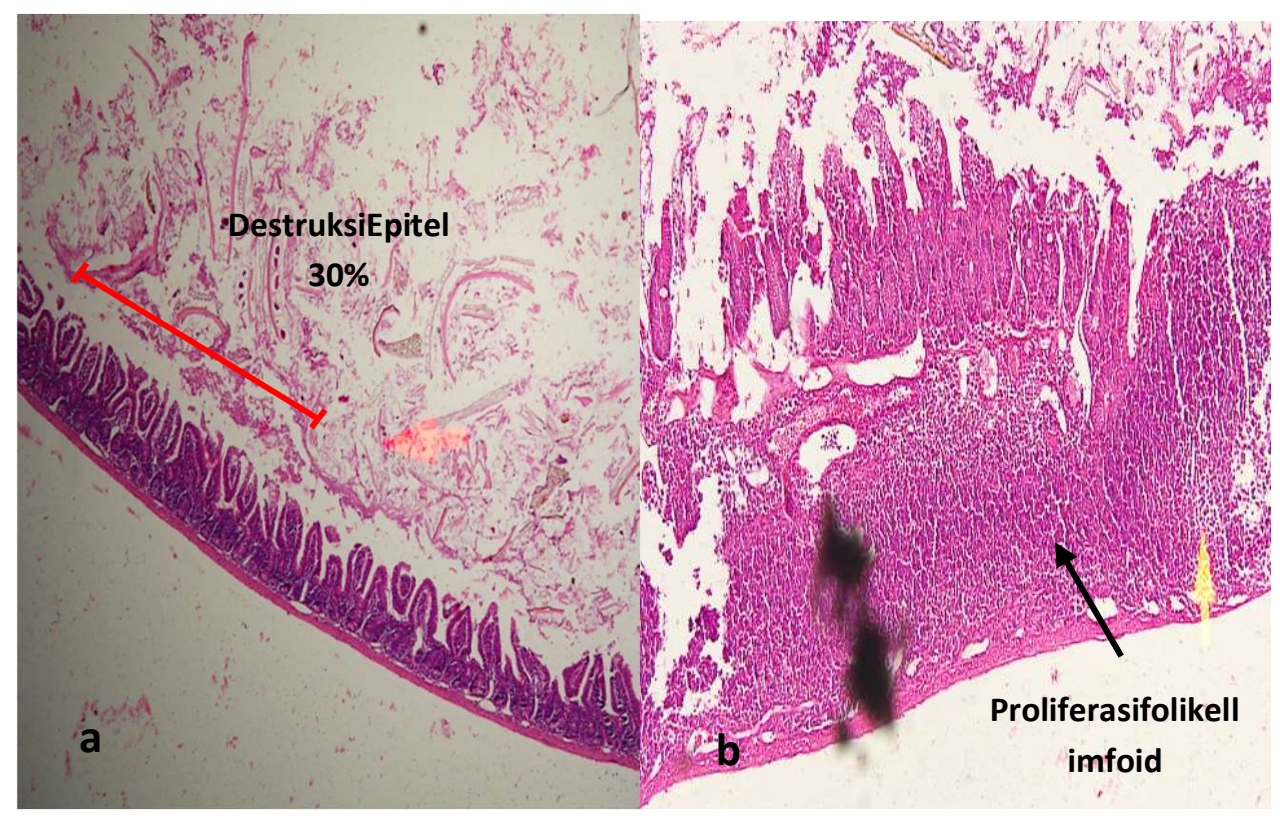

Gambar 1. (a) Destruksi epitel vili (30\%) serta (b) sebukan limfosit dan leukosit PMN di lamina propria, proliferasi folikel limfoid dilapisan submukosa 
Yusri Dianne Jurnalis: Pengaruh pemberian dadih terhadap keseimbangan mikroflora usus dan tinggi vili ileum

Lactobacillus plantarum dan Lactobacillus acidophilus sangat nyata lebih tinggi dibandingkan dengan tikus yang sakit tanpa diberikan probiotik. Penelitian oleh Yuliawati $^{4}$ di Padang juga menunjukkan peningkatan BAL yang sangat nyata setelah pemberian Pediococcus isolat dadih pada mencit diare.

Pada penelitian ini didapatkan rerata total koloni bakteri patogen lebih rendah pada kelompok perlakuan dibandingkan dengan kontrol positif dan negatif dengan perbedaan yang bermakna secara statistik. Penelitian Sujaya ${ }^{16}$ di Bali juga mendapatkan beberapa isolat BAL mampu menghambat mikroorganisme patogen. Penelitian lain oleh Aslinar ${ }^{17}$ di Padang juga menunjukkan bahwa pemberian Weissella paramesenteroides isolat dadih dapat menurunkan total koloni bakteri patogen secara bermakna pada mencit diare. Penelitian oleh Yuliawati ${ }^{4}$ di Padang juga mendapatkan penurunan total koloni bakteri patogen yang sangat nyata setelah pemberian Pediococcus isolat dadih pada mencit diare. ${ }^{4} \mathrm{Hal}$ ini didukung oleh pernyataan Adolfsson $\mathrm{dkk}^{18}$ bahwa Lactobacillus sp dari dadih mempunyai kemampuan menurunkan invasi bakteri patogen dalam usus.

Penghambatan BAL terhadap kuman patogen melalui produksi asam laktat serta asam organik lainnya seperti asam asetat dan hidrogen peroksida. Asam laktat yang dihasilkan BAL dapat memberikan efek bakterisidal untuk bakteri lain karena dapat menurunkan $\mathrm{pH}$ lingkungan menjadi 3-4,5 sehingga pertumbuhan bakteri lain akan terhambat. ${ }^{11}$

Rerata total koloni bakteri $E$. coli lebih rendah pada kelompok perlakuan dibandingkan dengan kontrol positif dan kontrol negatif dengan perbedaan yang bermakna secara statistik. Penelitian Aslinar di Padang juga mendapatkan rerata total kuman E. coli tampak mengalami penurunan sangat nyata setelah 24 jam pemberian Weissella paramesenteroides, sedangkan mencit yang diinduksi EPEC mengalami peningkatan rerata total koloni E.coli tiga kali dibandingkan dengan mencit normal. ${ }^{17}$ Hasil penelitian ini juga ditunjang oleh penelitian Arief $\mathrm{dkk}^{15} \mathrm{di}$ Bogor yang mendapatkan bahwa pemberian probiotik $L$. plantarum 2 C12 dan $L$. acidophilus $2 B 4$ mampu menurunkan total $E$. coli pada mukosa sekum dibandingkan dengan tikus yang dipapar EPEC tanpa diberikan probotik. Penelitian lain oleh Hartanti ${ }^{19}$ di Bogor juga mendapatkan bahwa jumlah E. coli pada feses tikus menunjukkan perbedaan yang berarti. Pada kelompok kontrol negatif jumlah E. coli relatif stabil, jumlah E. coli pada kelompok kontrol yang diberikan EPEC terjadi kenaikan yang sangat tajam, sedangkan jumlah E. coli pada kelompok perlakuan yang diberi Lactobacillus mengalami penurunan hingga akhir pengujian.

Umumnya, hasil penelitian ini sesuai dengan penelitian oleh Aslinar dan Yuliawati yang mendapatkan bahwa pemberian probiotik dapat memperbaiki keseimbangan mikroflora usus. Kesesuaian tersebut tampak pada jumlah bakteri usus yang stabil ditandai dengan peningkatan jumlah BAL. Jumlah bakteri $E$. coli yang rendah sebagai patogen dapat ditekan pada taraf yang tidak membahayakan bagi manusia. ${ }^{4,17}$

Pada penelitian ini didapatkan bahwa pemberian dadih tidak memberikan pengaruh yang bermakna terhadap perubahan tinggi vili ileum, tetapi pada mencit yang tidak diberikan dadih terlihat kerusakan epitel mukosa vili ileum. Penelitian ini sesuai dengan penelitian Torres $\mathrm{dkk}^{20}$ tentang pengaruh probiotik terhadap perkembangan saluran cerna Tores melaporkan bahwa tidak terdapat pengaruh pemberian probiotik dengan dosis bervariasi terhadap tinggi vili duodenum. Proses proliferasi sel mukosa usus tidak meningkat diduga karena adanya perbedaan respon inang terhadap probiotik yang dipengaruhi oleh jenis atau galur bakteri yang digunakan. ${ }^{21}$

Ditemukan bahwa pemberian dadih dapat menurunkan durasi diare 1-7 hari lebih cepat pada mencit yang mengalami diare akut. Didapatkan juga adanya pengaruh pemberian dadih terhadap keseimbangan mikroflora intestinal dengan meningkatkan total koloni bakteri asam laktat, menurunkan total koloni bakteri patogen dan E. coli. Dadih memproteksi epitel mukosa dari kerusakan akibat infeksi Enteropathogenic E. coli.

Walaupun demikian, penelitian ini mempunyai keterbatasan karena tidak menggunakan berbagai variasi dosis bakteri asam laktat di dalam dadih. Pada penelitian ini perlakuan pada mencit hanya selama 14 hari (diare akut), sehingga tidak dapat dilihat pengaruh dadih terhadap perubahan tinggi vili ileum

\section{Kesimpulan}

Terdapat pengaruh pemberian dadih terhadap keseimbangan mikroflora usus dengan meningkatnya total koloni bakteri asam laktat dan menurunnya total koloni bakteri patogen dan E. coli. Tidak terdapat pengaruh pemberian dadih terhadap tinggi vili ileum 
pada mencit yang mengalami diare akut, tetapi pada mencit yang tidak mendapat dadih terlihat kerusakan epitel mukosa vili ileum.

\section{Daftar pustaka}

1. World Health Organization (WHO). Diarrhoeal disease. 2013. Diunduh pada 5 Mei 2017. Didapat dari: www. who. int/mediacentrelfactsheets/fs330/en.

2. Dunowitz M, Alan NC, Richard H, Samuel B, Collins H. Significance of abnormal rabbit ileal histology in the pathogenesis of diarrhea. Infect Imnnunity 1979;26:380-6.

3. Diarlin SO, Ardyati T, Sjofjan O. Pengaruh lactobacillus fermentum dan lactobacillus salivarus dalam menghambat pertumbuhan bakteri patogen pada saluran pencernaan ayam pedaging (gallus gallus domesticus). Jurnal Biotropika 2013;1:236-41.

4. Yuliawati, Jurnalis YD, Purwati E, Lubis G. The effect of pediococcus pentosaceus on stool frequency, TNF- $\alpha$ level, gut microflora balance in diarrhea-induced mice. Indones J Gastroenterol Hepatol Digest Endosc 2012;13:97-102.

5. Borlioux P, Koletzko B, Guarner F, Braesco V. The intestine and its microflora are partners for the protection of the host. Am J Clin Nutr 2003;78:675-83.

6. Sudarmo SM. Peranan probiotik dan prebiotik dalam upaya pencegahan da pengobatan diare pada anak. Disampaikan dalam Kongres Nasional II Badan Koordinasi Gastroenterologi Anak Indonesia. Bandung, 3-5 Juli 2003.

7. Kusumo PD. Potensi probiotik dalam mekanisme sistem imunitas. Majalah Kedokt FK UKI 2010;27:184-93.

8. Surono IS. In vitro proniotic properties of indigenous dadih lactic acid bacteria. Asian-Australian J Animal Scis 2003;16:726-31.

9. Collado MC, Surono IS, Meriluoto J, Salminen S. Potential probiotic characteristic of lactobacillus and enterococcus strains isolated from traditional dadih fermentes milk against pathogen intestinal colonization. J Food Protect 2007;70:700-5.

10. De Keersmecker SC, Verhoeven TL, Desair J, Vanderleyden J, Nagy I. Strong antimicrobial activity of lactobacillus rhamnosus against salmonella thypimurium is ude to accumulation of lactic acid. FEMS Microbiol Lett 2005; 259:89-96

11. Kusmiati, Malik A. Aktivitas bakterisin dari bakteri leuconostoc mesentroides Pbacl pada berbagai media. Makara Kesehatan 2002;6:1-7.

12. Shinta K, Hatantyo, Wijayahadi N. Pengaruh probiotik pada diare akut: penelitian dengan 3 preparat probiotik. Sari Pediatri 2011;13:89-95.

13. Guarner F, Garisch J, Eliakim R. World gastroenterology organization practice guidelines: Probiotics and prebiotics. Arab J Gatroenterol 2009;0:33-42.

14. Caicedo RA, Schanler RJ, Li N, Neu J. The developing intestinal ecosystem: implication for neonate. Int Pediatr Res 2005;58:625-8.

15. Arief I, Jenie BS, Astawan A, Witarto A. Efektivitas probiotik Lactobacillus plantarum 2C12 dan Lactobacillus acidophilus 2B4 sebagai pencegah diare pada tikus percobaan. J Anim Sci Technol 2010;33:137-43.

16. Sujaya N, Ramona Y, Widarini NP, dkk. Isolasi dan karakteristik bakteri asam laktat dari susu Kuda Sumbawa. J Vet 2008;9:52-9.

17. Aslinar, Jurnalis YD, Purwati E, Sayoeti Y. Probiotic weisella paramesenteroides on enteropathogenic Escherichia coliinduced diarrhea. Paediatrica Indones 2014;54:1-8.

18. Adolfsson O, Meydani SN, Russel RM. Yoghurt and gut function. J Clin Nutr 2004;80:245-5.

19. Hartanti AW. Evaluasi aktivitas antidiare isolate lactobacillus dari air susu ibu (tesis). Bogor: Institut Pertanian Bogor, 2010.

20. Torres dkk. Effect of adding different levels of probiotics to broilers' diets on gastrointestinal tract development and production performance. Afr J Microbiol Res 2014;9:892-97.

21. Fuller R, penyunting. Probiotics: the scientific basis. London: Chapman and Hall; 1992. 